\title{
Progress and perspectives in aquatic microbial ecology: introduction
}

\author{
Paul A. del Giorgio \\ Département des sciences biologiques, Université du Québec à Montréal (UQÀM), CP 8888, succursale Centre Ville, \\ Montréal, Québec H3C 3P8, Canada
}

Our understanding of the structure and functioning of marine microbial communities has advanced very significantly over the past few years, driven in part by an explosion of genetic and phylogenetic data, as well as by detailed metabolic and biogeochemical data from a wide range of sites and systems. Nevertheless, the interfaces and links that exist between marine biogeochemistry, microbial ecology and molecular ecology are still tenuous and elusive (Höfle et al. 2008). In previous special issues of Aquatic Microbial Ecology (AME) we explored and discussed the complexities and challenges associated with the study of marine microbial diversity and structure (Fuhrman \& Steele 2008, Kuparinen \& Galvão 2008, Caron \& Countway 2009, Li 2009), and the difficulties of linking the patterns in diversity and composition to specific metabolic pathways in situ (Herndl et al. 2008, Raven 2009), and to major biogeochemical processes in surface oceans (Ducklow 2008, Gasol et al. 2008, Höfle et al. 2008, Weinbauer et al. 2009) and in deep ocean layers (Herndl et al. 2008, Tanaka 2009).

These challenges persist and, in fact, have in some ways expanded. In the past few years, there have been major technological developments, notably in the widespread application of massive sequencing techniques. These approaches yield large amounts of information on the structure of microbial communities, and in particular offer an unprecedented view of their rarer components. The generation of large amounts of data, however, does not automatically translate into greater ecological insight, unless there is an adequate framework within which to analyze and interpret these data. The technical advances are thus forcing the development of new conceptual, theoretical and statistical tools and frameworks (Pedrós-Alió 2007, Caron \& Countway 2009).

In this Special Issue of AME, we continue the exploration of emerging issues in marine microbial ecology, which are intimately related to the challenges discussed above. Pommier et al. (2010, this Special Issue) provide a concrete example of how pyrosequencing data may be used to assess bacterioplankton spatial patterns in coastal bacterial communities, and show major differences in community structure along a transect from the coast to open water, as well as with depth. Perhaps more importantly, they show how the actual patterns of diversity between stations vary when different portions of the 'rarity' spectrum are considered.

Pyrosequencing and other related, high-throughput techniques, carried out at broad phylogenetic levels have great potential to inform on patterns of distribution of rare and abundant microbial taxa. These techniques may also yield much insight into the distribution of key biochemical functions within these communities. In this regard, Riemann et al. (2010, this Special Issue) explore the distribution of nitrogenase activity beyond the commonly recognized diazotrophic picocyanobacteria, and show that biological $\mathrm{N}_{2}$ fixation is much more widely distributed than previously considered. These observations may have major consequences for our perception not only of the magnitude of marine $\mathrm{N}$ fixation, but also of the spatial and temporal heterogeneity of this key process.

There is no question that nitrogen plays a key role in shaping ocean metabolism, but in some marine ecosystems, such as the Mediterranean Sea, phosphorus plays a central role as well (Suggett et al. 2009). Where $\mathrm{P}$ is limiting, competition for the resource among the various microbial components is fierce (Tambi et al. 2009), and the outcome may in part shape the structure of microbial food webs. Thingstad \& Cuevas (2010, this Special Issue) explore the pathways of $\mathrm{P}$ acquisition and transfer within marine microbial food webs, using a combination of experimental data and modeling, and they show how the interaction between flexible stoichiometry and predatory processes may influence the speed and efficiency of P transfer.

Understanding the heterogeneity of microbial processes at different scales remains one of the main chal- 
lenges in marine microbial ecology. The water column of oceans and seas often appears to be relatively homogeneous, at least from the microbial perspective, yet we now know that it is populated by hundreds of thousands, if not millions, of individual genotypes. Smallscale spatial and temporal heterogeneities must play a role in the maintenance of this microbial diversity; in this regard, Tang et al. (2010, this Special Issue) explore the role that marine zooplankton organisms play as hotspots of bacterial diversity and activity in the oceans, and suggest that these hotspots have consequences for both the structure of marine microbial communities and major biogeochemical pathways.

$\mathrm{P}$ and $\mathrm{N}$ are intimately linked to phytoplankton and bacterial dynamics in coastal systems, and particularly to the development of algal blooms. One of the consequences of these blooms is the production of large amounts of exopolymeric compounds (Bar-Zeev et al. 2009), which may alter the physical and chemical structure of the entire system. The SAME 11 meeting was held on the shores of the Adriatic Sea, known for the periodic development of massive flocs of mucilage derived from algal blooms. It is appropriate then that Turk et al. (2010, this Special Issue) explore the physical, biogeochemical and ecological implications of mucilage macroaggregates, and their interactions with microbial communities.

Microbial communities clearly play a major role in shaping marine biogeochemistry, but Liu et al. (2010, this Special Issue) explore the reverse link: How may shifts in marine chemistry, more specifically through ocean acidification, influence the structure and functioning of marine microbial communities? There is no simple or direct response to this question, but these authors provide a much-needed synthesis of the current literature and key insights into future avenues of research.

The SAME 11 meeting revealed once again the steady progress that is being made in our discipline in addressing existing problems and paradigms. It also highlighted the excitement of emerging questions and challenges. This Special Issue of AME effectively captures the progress, the excitement and the challenges that lie ahead, and I thank the contributors for sharing with our community their achievements and vision.

\section{LITERATURE CITED}

Bar-Zeev E, Berman-Frank I, Stambler N, Vázquez Domínguez E and others (2009) Transparent exopolymer particles (TEP) link phytoplankton and bacterial production in the Gulf of Aqaba. Aquat Microb Ecol 56:217-225

Caron DA, Countway PD (2009) Hypotheses on the role of the protistan rare biosphere in a changing world. Aquat Microb Ecol 57:227-238
Ducklow H (2008) Microbial services: challenges for microbial ecologists in a changing world. Aquat Microb Ecol 53: 13-19

Fuhrman JA, Steele JA (2008) Community structure of marine bacterioplankton: patterns, networks, and relationships to function. Aquat Microb Ecol 53:69-81

Gasol JM, Pinhassi J, Alonso-Sáez L, Ducklow H and others (2008) Towards a better understanding of microbial carbon flux in the sea. Aquat Microb Ecol 53:21-38

Herndl GJ, Agogué H, Baltar F, Reinthaler T, Sintes E, Varela MM (2008) Regulation of aquatic microbial processes: the 'microbial loop' of the sunlit surface waters and the dark ocean dissected. Aquat Microb Ecol 53:59-68

> Höfle MG, Kirchman DL, Christen R, Brettar I (2008) Molecular diversity of bacterioplankton: link to a predictive biogeochemistry of pelagic ecosystems. Aquat Microb Ecol 53:39-58

Kuparinen J, Galvão H (2008) Microbial ecology: from local to global scales. Aquat Microb Ecol 53:3-11

Li WKW (2009) From cytometry to macroecology: a quarter century quest in microbial oceanography. Aquat Microb Ecol 57:239-251

> Liu J, Weinbauer MG, Maier C, Dai M, Gattuso JP (2010) Effect of ocean acidification on microbial diversity and on microbe-driven biogeochemistry and ecosystem functioning. Aquat Microb Ecol 61:291-305

> Pedrós-Alió C (2007) Dipping into the rare biosphere. Science 315:192-193

Pommier T, Neal PR, Gasol JM, Coll M, Acinas SG, Pedrós-Alió C (2010) Spatial patterns of bacterial richness and evenness in the NW Mediterranean Sea explored by pyrosequencing of the 16S rRNA. Aquat Microb Ecol 61:221-234

Raven JA (2009) Contributions of anoxygenic and oxygenic phototrophy and chemolithotrophy to carbon and oxygen fluxes in aquatic environments. Aquat Microb Ecol 56: $177-192$

Riemann L, Farnelid H, Steward GF (2010) Nitrogenase genes in non-cyanobacterial plankton: prevalence, diversity and regulation in marine waters. Aquat Microb Ecol 61: 235-247

> Suggett DJ, Stambler N, Prášil O, Kolber Z and others (2009) Nitrogen and phosphorus limitation of oceanic microbial growth during spring in the Gulf of Aqaba. Aquat Microb Ecol 56:227-239

> Tambi H, Flaten GAF, Egge JK, Bødtker G, Jacobsen A, Thingstad TF (2009) Relationship between phosphate affinities and cell size and shape in various bacteria and phytoplankton. Aquat Microb Ecol 57:311-320

Tanaka T (2009) Structure and function of the mesopelagic microbial loop in the NW Mediterranean Sea. Aquat Microb Ecol 57:351-362

> Tang KW, Turk V, Grossart HP (2010) Linkage between crustacean zooplankton and aquatic bacteria. Aquat Microb Ecol 61:261-277

Thingstad TF, Cuevas LA (2010) Nutrient pathways through the microbial food web: principles and predictability discussed, based on five different experiments. Aquat Microb Ecol 61:249-260

Turk V, Hagström Å, Kovač N, Faganeli J (2010) Composition and function of mucilage macroaggregates in the northern Adriatic. Aquat Microb Ecol 61:279-289

Weinbauer MG, Bettarel Y, Cattaneo R, Luef B and others (2009) Viral ecology of organic and inorganic particles in aquatic systems: avenues for further research. Aquat Microb Ecol 57:321-341 